\title{
EFL STUDENTS' VOICES ON LEARNER AUTONOMY AT A UNIVERSITY IN THE MEKONG DELTA
}

\author{
Le Thanh Nguyet Anh* \\ Ph.D. Student, University of Foreign Languages, Hue University \\ Faculty of Foreign Language Education, Dong Thap University, \\ 783 Pham Huu Lau, Ward 6, Cao Lanh, Dong Thap, Vietnam
}

Received 15 January 2018

Revised 11 March 2018; Accepted 30 March 2018

\begin{abstract}
The present study aimed to investigate students' learner autonomy (LA) at tertiary education in Vietnam. The study participants were 60 English as a Foreign Language (EFL) students from a single rural university, South Vietnam. Narrative interview was used to collect the required data. The findings disclosed that most of them had positive views of LA as well as its role at higher education. Yet, in LA practices, they gained achievements of different degrees and related problems were found. Thereby, it implied that since LA was a long process, students should patiently keep on cultivating it by virtue of both their own sufficient ongoing efforts and instructor's supports in need.
\end{abstract}

Keywords: learner autonomy, student, EFL, learning, practice

\section{Introduction}

In the past years, researchers have studied the importance of autonomy in second language learning. Autonomy plays a vital role in language education because in any educational contexts, learners are autonomous when they establish their own learning goals and have responsibility for planning, managing and evaluating particular learning activities and the learning process overall. In the changing setting of English language teaching and learning in the $21^{\text {st }}$ century, LA is deemed to be an important goal in the teaching and learning process. Hence, Vietnamese Ministry of Education and Training (MOET) has conducted the Law of Higher Education to enhance the quality of the tertiary educational system approaching international standards in the $21^{\text {st }}$ century. Recently, MOET has integrated and developed LA in the credit education system. A number of new policies have been issued.

\footnotetext{
* Tel.: 84-1299898188

Email: 1tnanh@dthu.edu.vn
}

At Article 40, the Vietnamese Education Law (National Assembly of Vietnam, 2005) mentions the requirements on contents and methods of education in higher education, in which LA plays a crucial role: "Training methods in higher education must be brought into play to foster the learners' ability to be active learners, to study and research by themselves, and to foster their practical abilities, self-motivation, creative thinking, and ambition" (p.13). Therefore, teaching and learning methods in tertiary education need to be promoted with three main aims: (1) fostering students to learn, self-research autonomously and actively, (2) increasing their creative thinking and practical abilities, (3) cultivating their self-motivation and ambition to achieve life-plans. What is more, in the developmental education policy in 2011-2020 period, accompanying the Decision number 711/QD-TTg, 13 June 2012 issued by Prime Minister (Vietnamese Prime Minister, 2012), the Government has identified to go on innovating teaching methods and assessment, training students 
with the aim of developing their activeness, creativity, and learning autonomy.

However, for certain reasons, traditional teaching and learning English, or teachercentered approach in Mekong Delta still somehow exists, (especially in local colleges/ universities where most freshmen are at low academic level) although educational reforms of English subject in Vietnam have been conducted for over ten years. In the rapid technological information era these days, students can easily use a wide variety of technological devices for English learning (Hoang, 2017). As a consequence, teachers' role should change so as to help students to foster their LA ability effectively. Moreover, like many other countries in the world, Vietnam higher education has applied a credit system for recent years. Under this system, students are required to rely more on themselves in learning rather than on their instructors in classroom. The problem that appears here is how students are able to study independently of teachers given that they did not experience this during high school.

Although there have been a number of studies of EFL students' perceptions and practices regarding LA in Asian contexts generally and in Vietnam particularly (i.e. Balcikanli, 2010; Chan, Spratt, and Humphreys, 2002; Dang, 2012; Joshi, 2011; Le, 2013; Talley, 2014), their results have yet to be comprehensively generalized and final conclusions of this field have yet to be made. Hence, further research needs conducting about this field in such rural areas as in the Mekong Delta, South of Vietnam, especially in Dong Thap University (DTU). The present study makes an attempt to clarify this as well as to provide more insights about LA in the views of Vietnamese-speaking EFL students, who are actually the insiders of the LA developing process.

\section{Literature review}

\subsection{Learner autonomy and theoretical framework for the study}

A number of definitions of LA in language education have been established so far. Holec (1981) defined it as the "ability to take charge of one's own learning” (p.3). Wenden (1991) believes that autonomous learners are the ones who "have acquired the learning strategies, the knowledge about learning, and the attitudes that enable them to use these skills and knowledge confidently, flexibly, appropriately and independently of a teacher" (p.15). Similarly, Littlewood (1999) identifies autonomy should consist of two characteristics: (1) Learners should have a duty to their learning process; (2) Learners have to design their learning objectives, find their learning styles and assess their learning process. Little (1999) claims that autonomy is a popular kind of learning and can apply in any culture. Then, Little (2000) highlights the notions of individuality and independence as being the nucleus of the concept of LA. Holliday (2003) suggests a type of LA which learners can learn after school. Meanwhile, Nguyen (2014) states "learner autonomy is defined as learner's willingness, and ability to take responsibility, to plan, implement, monitor and evaluate his/her learning with tasks that are constructed in negotiation with and support from the teacher" (p.21). Alhaysony (2016) lists different definitions of LA defined by many language researchers and concludes that most of them have focused on learners' "ability, capacity, take responsibility, take control, learner's demonstration, attitude, willingness, mode of learning" (p.46).

Thus, current definitions of LA are not unanimously shared by researchers around the world, probably because LA is a multidimensional construct. It, however, unanimously includes (1) the learner's awareness of his/her learning responsibility 
at the baseline dimension; and at the higher ones (2) ability and willingness to set learning plans/objectives, (3) choosing methods, strategies, resources to perform learning actions with and without instructor assistance, and (4) evaluating/self-assessing learning processes and outcomes.

With the purpose of investigating EFL students' perceptions and practices regarding LA, this LA framework of four major dimensions is chosen for this study.

\subsection{Learn autonomy role in EFL higher education}

Learner autonomy is recently one of the central topics and a major objective, especially in higher education (Sinclair, 2000). Moreover, LA can make learners gain their creation and independence at high levels. In recent years, there has been a growing body of research evidence about LA benefits and the importance of fostering it in foreign/second language education. More specifically, Dafei's (2007) results proved that learners' English competence had a close-knit relationship with their LA ability. It means that when learners have good LA ability, they will learn language better and vice versa. In Balcikanli's (2010) study, when students had chances to decide their learning process, they showed their positive attitude and it made their learning more and more focused and purposeful. However, it was difficult for them to involve in making decisions on some aspects such as choosing time and place of a class, or selecting materials in learning because they were not allowed.

Additionally, Borg and Al-Busaidi (2012) found out that $93.4 \%$ of teachers agreed LA contributes to language learners' success remarkably. In addition, Dang (2012) indicates LA "directly contributes to both processes and outcomes of learning activities" (p.26), helps "students to face the challenge of technical difficulties", and "is especially important for knowledge construction and sustainable learning in today's globalized world" (p.27). And for Bajrami (2015), LA has promised "the positive outcomes at the university level, such as flexibility, adaptation, self-initiative, and self-direction" (p.149). Also, Duong and Seepho (2014) indicate that LA has had an important role in both academic study and teaching practices in the $21^{\text {st }}$ century step by step. According to new standards in education today, students are taught not only knowledge but also the methods of LA. In a new millennium, a modern education of a country should give a lot of attention to the complete student like a thoughtful, emotional, creative individual who has become a responsible citizen of that country.

And one more major reason for continuing exploring and developing LA at tertiary education is for the purpose of life-long learning for students. According to Thomson (1996, p.78), language learning is "a life-long endeavor". LA lays the foundation of lifelong learning. Jacobs and Farrell (2001) show that LA emphasizes the process of learning and students have to "see learning as a lifelong process" (p.5). Borg and Al-Busaidi (2012) consider LA "prepares individuals for lifelong learning" (p.3). Azizi (2014) indicates that LA is "a matter of lifelong process rather than a need for a particular situation or course" (p.130). In addition, LA is the necessary base of learners' lifelong learning process after they graduate university. It is of course possible to apply this idea to English lifelong learning.

Recently, some Vietnamese researchers have studied LA in language learning in different approaches in the Vietnamese university context. More specifically, Trinh (2005) focused LA on curriculum for EFL students at Can Tho University. He used a three-dimension model of planning, monitoring, and regulating to conduct his study. Next, Nguyen(2009) worked on creating 
autonomous students basing on learner-based approach and the task-specific training, and focused on strategy-based instruction by using a model with two dimensions, namely self-initiation and self-regulation in Writing 4. After that, Dang (2012) explored EFL students' perceptions and performances of LA in online and offline learning environments through developing a four-dimension model, namely monitoring, initiating, goal-setting and evaluating, and using Information Communication Technologies. Moreover, Le (2013) studied Vietnamese students' belief about and performance of LA, and designed an integration between learner training with language courses of Listening and Speaking 3 at a private university in Ho Chi Minh City, Vietnam. Additionally, Nguyen (2014) presented EFL teachers' beliefs about LA in university level in Hanoi. She found that nearly $40 \%$ of participants considered that their students could manage their own learning process. Up to $85 \%$ of them believed that they had a duty to decide learning objectives, to choose learning content as well as to evaluate students' learning process.

The studies cited above have focused on promoting LA in main big cities such as Can Tho City, Ho Chi Minh, and Ha Noi in Vietnam. Although they have different approaches toward the ongoing issue, one common thing among them is the concern related to application of LA into the Vietnamese context. Besides, those studies used questionnaires and interviews, especially semi-structured for focus groups to explore the findings. From the above research results, it is currently raising the concern among EFL teachers (the present author included) at DTU whether or not these growing reported results through narratives are reasonably and comprehensively applied to the case of EFL students at this rural university, and if based on the 4-dimensional LA framework, where do they appear to demonstrate? This concern has motivated the present study.

\section{Research method}

\subsection{Research questions}

To its end, the present study needs to answer the three following questions:

1. What do EFL students perceive of LA?

2. What have they done to develop LA?

3. How do students self-assess their LA?

\subsection{Participants}

They were 60 English majors from Faculty of Foreign Language Education, Dong Thap University, South Vietnam (www.dthu.edu.vn), where the author has been working as an EFL lecturer for nearly 10 years. They were 6 males and 54 females from 18 to 22 years old (which represented well a male-female student ratio in this faculty in the current years), including 15 freshmen, 15 sophomores, 15 juniors, and 15 seniors (2016-2017 academic year). After being fully informed of the purpose of this study by the author, all of them volunteered to join and answered narrative interview questions relating to both their perceptions of LA and what they had done to develop LA in their learning. It should be noted that none of them had ever attended any training programs exclusively on EFL students' LA.

\subsection{Data collection instrument}

\section{Why is narrative interview used?}

As a research tool in a qualitative research, narrative interviews are considered as "unstructured tools, in-depth with specific features, which emerge from the life stories of both the respondent and cross-examined the situational context" (Muylaert et al, 2014, p.185). Additionally, they confirm that narrative interview is a research tool to be able to contribute to a specific study area and someone's critical reflection. Furthermore, given that they are all peers 
from the same university, group interview is clearly a more favorable environment for their reflection than individual interview because they tend to positively stimulate one another to talk. Meanwhile, no previous LA studies (Dang, 2012; Le, 2013, Nguyen, 2009) used exclusively narrative interview. Thus, exclusively using narrative interview in groups of five as a data collection tool (with a larger number of participants, mentioned just above) made a principal difference between this study and the previous ones. Additionally, the reason for narrative interview to be used was to help the current researcher explore EFL students' perceptions and practices based on the 4-dimensional LA framework as presented above. Interviewing questions were divided into three parts: (1) students' perceptions of LA in language learning at higher education, (2) students' reflections on their LA practices, (3) students' self-assessment of their LA ability (see Appendix). It aimed to have EFL students tell what they thought about LA and what they implemented LA activities outside classroom. The information collected from the students' anecdotes helps to answer the three research questions above.

\subsection{Procedure}

All 60 students took part in the interview face-to-face in groups of five about one hour for each. Students were asked to share their cognition of LA and tell how they practiced autonomous learning in their early and current learning. For convenience and absolute understanding, the interview was administered in Vietnamese, and was all recorded by the researcher. Every participant was coded. For instance, student No.1, No.2, No.3 was coded $\mathrm{S} 1, \mathrm{~S} 2, \mathrm{~S} 3$ and so on. Every group recording was saved in a separate file. After the transcription finished, it was sent back to the participants, respectively, in both Vietnamese and English version by the researcher for confirmation and back-checking. The transcription was then read carefully several times by the current researcher to code meaningful categories. Then, based on above framework, transcribed and translated information from narrative interviews of EFL students was being analyzed to respond question 1,2 , and 3 . These qualitative data were interpreted their meaning to be considered the reality of how students understand the concept, the role of LA at university environment and what they did or did not carry out LA outside classroom.

\section{Findings}

\section{What do students perceive of LA?}

In the interview, 60 participants showed their LA perceptions in three main concepts as "ability", "responsibility", and "attitude".

First, for them, LA means "ability" to analyze their needs, set up objectives and design clear study plans for gaining high results (5\% of interviewed students), to arrange time to self-study (5\%), to control and divide time to learn each skill of English equally $(3.3 \%)$, to balance time to study inside and outside classes, and join other daily activities $(3.3 \%)$, or learn to know scientific learning methods $(1.7 \%)$.

Second, it involves their "responsibility" to autonomously prepare and search learning materials/resources and before or after classes for better class-participations and understandings, especially English language skills and culture (5\%), to watch English movies or music to develop new words (3.3\%), to practice English with foreigners in case they come across them (5\%), to make groups for self-study $(3.3 \%)$, to actively participate in school extra-curriculum activities (3.3\%), even to consult upper-class students for learning experiences $(1.7 \%)$, and make reflections on what has been done for reinforcements $(1.7 \%)$.

Third, it also includes their "attitude" towards English learning. More specifically, 
students should have passion and enthusiasm in learning autonomously $(1.7 \%)$, be able to control themselves in all aspects of learning achievements instead of relying totally on instructors $(1.7 \%)$, i.e. carry out autonomous learning without waiting for their teachers' instructions $(1.7 \%)$.

When asked about the importance of LA to EFL students during university life and later, all 60 informants $(100 \%)$ agreed that it was significantly important.

Their typical accounts are "I think autonomy is prerequisite to determine a student's learning quality. Through it, students can find more knowledge resources than learning in the classroom" (S16), "Learner autonomy occupies $90 \%$ learning results of students as well as makes a chance for them to get a job. If we have learner autonomy ability, we will have benefits at work in the future" (S34), "Up to 80\% of English-major students" success will be determined by their learner autonomy ability, and even when at work in the future" (S59), "If they [English-major students] do not learn autonomously, not self-research, and not self-find materials on the Internet, they cannot gain their learning objectives established at the beginning of the course" (S15), or "If students learn it autonomously, their ability of using English language is getting gradually better and better because learning English is a long process" (S52).

Most of them concurred that teachers could not convey all relevant knowledge in class and the information or the lecture that teachers delivered to students was just basic knowledge because of the limited time; therefore, they had to self-study at home to improve their learning results. And some stated that teachers only orientated their learning methods or guided them how to learn and thus if they did not have their own LA ability, they could not be excellent in English or widen their knowledge though they were taught by good teachers and that teachers hardly understood all about their students' learning ability and students themselves knew well where their learning level was; therefore, autonomy helped them improve their weaknesses as well as develop their strengths.

What have students done to develop LA?

The most interesting section in the interview process was that every and each student took turn to narrate their real LA activities at university. They all eagerly shared ways to learn English outside classes, set up goals, plan study, revise previous lessons, arrange time reasonably to learn, and look for materials. The following are typical ones.

For S11, she is a sample of doing homework more than other LA activities. She practiced listening to PET, KET, videos, music much, and watching movies in English. She rarely practiced writing skills, but often did TOEFL reading tests. She just revised grammar because she had no difficulty in learning it. For Speaking, she imitated English songs and found some topics to practice. Furthermore, she did homework given by her teachers and other exercises found by herself. She spent more time on doing homework more than others. She just set up general goals such as getting A marks or winning a scholarship. Her long-term goals were to graduate from university in time with a good Bachelor Certificate and to get a job. Additionally, she could balance her time for her daily activities and her study; however, she thought she arranged her time for learning autonomously and other activities unreasonably because she still stayed up late to learn her lessons. She found materials recommended by her teachers such as englishtips.org, Cambridge website, Oxford website. Normally, after school, she revised her lessons again and when she had tests she would review them again.

Meanwhile, S16 is a typical example for practicing Speaking more. He had a study plan at the middle of the first semester. 
He practiced Speaking by means of ELSA Speaker and English-English dictionaries. He listened to them and repeated. He analyzed and memorized each type of writing; then practiced writing introduction and conclusion as well as body paragraphs. Besides, he watched Mr. Dan's videos and listened to English songs but did not understand them completely. When coming across new words, he looked up them in the dictionary as well as their synonyms, antonyms, and usages. He said that he was finding the most effective way to learn grammar since he found that learning grammar by heart was not effective. Therefore, he had to find some tips to memorize it more deeply. Besides, the time he learned autonomously was not fixed because of his timetable in classes, daily activities, university or class activities, so he practiced LA about thirty minutes in the morning, and thirty minutes in the afternoon. In general, he spent about two hours of four days a week learning autonomously.

For S36, he seems to be a student using many types of learning resources. He explored various resources for learning: read BBC news, listen to tapes in textbooks or IELTS books of Cambridge from volume one to volume nine, use Cambly software to practice speaking three times a week (The software allowed him to speak directly to foreigners from seven to ten minutes), and go to the library to read topics, write them, and submit them on Making Mate web to be corrected. On the contrary, S17 was very conscious of her childlike learning style in that she watched English videos and repeated, and listened to English stories to relax. And this is how S22 learned English vocabulary: he wrote one word he did not know, and then omitted vowels; then wrote many words and did the same. After ten minutes, he remembered vowels and filled them again. This made him impressive and easy to learn vocabulary. But S23 shared a different way to learn English vocabulary: she wrote new words on small pieces of paper and stuck them on the wall so that she could see them to memorize.

When asked about advantages of practicing LA activities outside classroom, all 60 students responded that they achieved a lot. First, they got new knowledge, websites, and materials $(21.7 \%$ of students) because they learned what they liked first, and they understood what they liked faster $(10 \%)$. Second, they could memorize lessons more clearly, deeply, and longer, and what they found when they learned autonomously belonged to theirs (15\%). Third, they felt learn autonomously at home more comfortably and effectively than in class (13.3\%). Next, learning English autonomously made them feel good and inspired (11.7\%). Besides, they saw that they actively used their time (13.3\%), and increased self-consciousness (3.3\%). They could find which fields they were weak to improve $(8.3 \%)$, ask their friends $(5 \%)$, and summarize their lessons (1.7\%). Also, they gained autonomous learning experience $(6.7 \%)$, more effective learning methods $(3.3 \%)$ and problem-solving skills $(6.7 \%)$.

With regard to possible difficulties, many of them found that it was hard for them to selfassess their LA assignments or to ask whom for help. For instance, S27 said that after writing papers/essays, she needed someone to correct them to help her know where she was wrong, but she had no one. Or when making an essay outline, she thought of many ideas and selected main ones put into three body paragraphs; however, when writing essays she only used the words she already knew before. After that she opened her notebook and saw that she wrote good words in it, but could not apply or use them. Thus, she felt her memory which was not bad, and did not know why it was. So, she felt somehow angry at herself, and had no solution to that problem. 
For S31, she could not learn in groups for four skills of English because she and her friends had different timetables, while S39 revealed that although she liked to read bilingual stories such as Harry Potter any time during the day and understood them, she could not answer the questions that followed. Interestingly, S58 confessed that since there was no one controlling her, she easily neglected her learning duty or plans. Or they were easily attracted by other inducements (28.3\%) such as chatting, going out with friends, surfing webs, Facebook, Zale and so on.

Next, some students considered that their alone learning was not effective, especially in speaking skill $(13.3 \%)$ and their living environment was noisy (5\%). They did not have enough techniques to search materials in the library $(1.7 \%)$. Or when they wanted to share or ask something with their friends, they were not available online (1.7\%).

\section{How do students self-assess their LA?}

Most of the interviewed students evaluated their LA poor (13 out of $60,21.6 \%$ ) or around average (over 50\%), while the rest $(7 / 60$, $11.7 \%$ ) self-assessed their LA good. Some detailed accounts are provided below.

For S53, she felt her LA ability was effective since when undertaking her study plans, she gained certain promotions. In the same line, S54 found that LA implementation enabled her to reap better learning results. By virtue of LA practices, she usually discovered something new and interesting. That stimulated her to explore it more and increased her LA time. Meanwhile, S59 explained her increasing LA efficacy in the sense that despite her poor LA capability, she found her LA ability during the late college semesters was increased significantly more than when she was as a high school student. At high-school time, the concept of LA seemed very strange to her. Similarly, S57 said that comparing with the first year; she self-assessed her LA ability better in her second year. Unfortunately, S52 and 60 considered that their LA ability was ineffective because they had no clear learning goals, were unable to successfully fulfill study plans as expected or were somehow affected by unwanted incidents like health problems, extra-curriculum activities, family or friendship affairs. Thus, S10 admitted that LA is crucial but difficult to put into practice.

The data of this study were analyzed according to the framework of four dimensions mentioned above. The results proved that this framework is completely suitable for this research to investigate EFL students' perceptions and practices regarding LA.

\section{Discussion and implications}

The findings confirm that all the students have clear insights of LA as ability, responsibility, and attitude in language learning (at the baseline dimension of LA). In other words, they know what they should do to be EFL autonomous learners at university. Furthermore, all of them are aware of the vital role of LA for students in higher education and after they graduate from university (i.e. life-long learning).

At the higher dimensions (ability and willingness to set learning plans/objectives; and choosing methods, strategies, resources to perform learning actions with and without instructor assistance), they did set up their own learning objectives, their learning plans (though not all of them functioned well); they actively chose suitable methods, strategies, materials subject to their learning styles and looked for materials and learnt by themselves without waiting for teachers' instruction or request; they autonomously practiced four skills of English, learnt new words and grammar structures as well, got prepared before class, and asked teachers or others in case of having problems; they took part in college extra-activities, and had selfconsciousness in learning. These findings echo those in the previous studies (i.e. Azizi, 
2014; Balcikanli, 2010; Chan et al, 2002; Dang, 2012; Joshi, 2011; Le, 2013).

However, basing on Nunan's (1997) fivelevel sample of learner action continuum running from awareness, involvement, intervention, creation, and transcendence, it cannot deny that EFL students' LA ability at DTU just got levels of awareness and involvement of LA. In other words, most students were aware of what they should do to become autonomous learners and involved in some LA activities while a few of them got level "intervention" like modifying and adapting the goals and content of the learning program. Also, Scharle and Szabó (2000) when discussing the growth of autonomy introduced a three-stage model as "raising awareness", "changing attitudes", and "transferring roles" (p.1). According to Bodenhausen and Hugenberg (2009), one's perception guides his/her actions. From the results of this theme, although students had their positive perceptions of LA, its vital role at higher education, as well as advantages of LA in learning English, they have not gained the highest rest. They had their certain difficulties to conduct LA activities outside the classroom as S10, S59, and S60 stated above. Moreover, Littlewood (1999) developed definition of learner autonomy in two levels of proactive autonomy and reactive autonomy. He indicates that East Asian students own reactive autonomy as Western ones get proactive autonomy. In the way of proactive autonomy, learners work individually and set up their "directions which they themselves have partially created" while reactive autonomy "which does not create its own directions but, once a direction has been initiated, enables learners to organize their resources autonomously in order to reach their goal" (p.75). So, in case of EFL students at DTU, they still possessed reactive autonomy like ones somewhere in East Asia.
In comparing with the findings of the previous studies of LA in Vietnamese setting, this study has obtained its own values in this field. For example, the number of interviewed students in this study is 60 , more than all previous others and they were from freshmen to seniors while Nguyen (2009) and Dang (2012) both interviewed 11 ones; and Le (2013) interviewed 18 ones in three focus groups. Interviewing 60 students helped the current researcher get huge, various data to explore and then to give reliable results for this study. Additionally, students could learn LA methods each other when interviewing groups of five students was conducted. Next, researching purposes of using interview tool in those studies are different. Nguyen (2009) used interview to ask students about three purposes: (1) their strengths and weaknesses in learning English and their understanding of "student and teacher responsibilities in learning process" (p.121), (2) their "writing behaviors", (3) their activities to enhance English inside and outside the classroom while Dang (2012) reported his interview data to discuss effect of preference on LA, effect of motivation on LA, and effect of attitude on LA. Also, Le (2013) asked her interviewed students about their assessment of the effectiveness in implementing the learning contract and writing the learning diary. Meanwhile, narrative interview in this study was used with the aim of creating many opportunities for students to talk about their LA activities, their benefits, their difficulties, their needs, as well as their self-assessment of their LA activities more clearly, in details and emotionally which the researcher maybe did not find in questionnaire. The results of this study showed that students reported their LA process in different ways depending on their learning styles and their kinds of multiple intelligences they possess. In addition, although they had a common in practicing 
four skills of learning English, vocabulary, and grammar, they conducted LA activities according to their hobbies, their needs, their strengths, and their weaknesses, and had their own autonomous learning method as shown above. This cannot be found in questionnaire or in previous studies.

Thus, EFL learners, including those from DTU, now have positive views on LA values. Thereby, the present study also reflects EFL learners' current vision of the necessity to develop LA one way or another. As mentioned above, although EFL students from DTU entered college education with low entrance grades and none of them have attended any exclusive training on LA training courses, they are all aware of its crucial role and are trying their best to develop it in language learning. And gladly, they did acknowledge achievements of different degrees thanks to LA practices at the college setting, which was unknown to them in the previous education. As a result, they are all moving on the right tracks of LA development, though not at the same pace and level. This is quite understandable because LA ability is made up of multiple dimensions and two students are not exactly the same in terms of personal traits, learning styles and characteristics.

Thanks to narrative interview, the researcher could find out learners' experiences at real school contexts because it gave a clear, deep, real, particular understanding of complicated problems or situations (Creswell, 2012). Therefore, the present findings also confirm that there still exists quite a noted mismatch between what students perceived and what they actually obtained from LA developments through their stories about their perceptions and practices of LA activities. Most of them responded in the interview that they did not know how to set up their specific learning goals at the beginning in the first year or they only established general goals.
Normally, after one or two first semesters, they began to set up their specific goals. A large number of them did not have their own learning plan daily or weekly. There are some students who designed their study plans but did not make it effective because they did not manage their time for these plans or were attracted by other unplanned activities or lacked sufficient efforts and strong will. They confided that they easily felt bored when learning alone. Specially, when they surfed the Internet, they were easily attracted by social websites such as chatting with their friends on Facebook instead of paying attention to their learning practice. In addition, most of them have not known what websites on the Internet are reliable to study. One more difficult thing they met was that they had no one to share their problems or to correct or explain their writings or their LA exercises or practice tests. Clearly, the relationship between their perceptions and their practices is not strong. All this, on the one hand, says that the present students appeared to be proceeding to dimension 4 of LA ability, where they self-assessed and reflected on the outcomes realizing relevant constraints. On the other hand, it shows that LA does not mean an absolute absence of teacher role, especially at the first college stages.

As educators, teachers should understand learners' perceptions and their needs towards LA to be able to promote LA in many aspects. It is implied that EFL students at DTU have lacked LA skills because they were not trained those ones at schools before. To solve these problems, consequently, it is advisable that at the very first semester of the training course, EFL students should be made fully aware of LA by instructors in charge, specifically they should be guided (1) how to set up feasible learning goals, based on a thorough analysis of their individual needs, strengths and weaknesses, (2) make compatible plans down to monthly, weekly and daily ones if possible, 
and appropriately choose learning methods, strategies, activities and materials for the set goals, (3) consciously and closely monitor learning processes to constantly ensure things going right, (4) patiently work hard and build effective ways to combat stress, boredom and other unexpected problems or out-of-plan inducements, (5) frequently make reflections, self-assessments and draw experiences from what have been done.

Secondly, this guidance should be regularly repeated throughout the training course to reinforce LA ability. Thirdly, instructors should always get prepared to willingly provide further guidelines, assistance and encouragements in case students get astray, feel demotivated and search for help or feedback on their ways because LA is a longterm process, even throughout an entire life.

\section{Conclusion}

The present study has provided evidence about EFL students' perceptions of LA role and their practice of LA in the Mekong Delta context. Although placed in a rural area and never trained exclusively on it before, they all have positive perceptions towards the LA role for college success and later life, and fully awareness of their learning responsibility. Furthermore, they are trying various ways to reach the set learning goals. Since LA is multidimensional and developed throughout one's college time and later life, what the interviewed students have gained is rather limited and it also uncovers spaces where they face problems and need supports and feedback. Thus, the present study maintains the instructor's clear, specific and helpful guidance, not only right at the beginning at but also during the training program whenever students, especially less strong ones, are in need because most students trust their teachers and think that they can learn something new from them (Wang, 2010), and because while students are still in short of self-discipline in learning, teachers might interfere to guarantee that learning happens (Yao \& Li, 2017).

\section{References}

Alhaysony, M. (2016). An Investigation of EFL Teachers' Beliefs and Practices of Learner Autonomy. International Journal on Studies in English Language and Literature, 4(12), 45-59. Available through $\quad<$ http://dx.doi.org/10.20431/23473134.0412009>, Accessed 22/01/2017 07:55

Azizi, S. (2014). Iranian EFL Learners' Perception of Autonomous Language Learning in Language Classrooms. Journal of Studies in Learning and Teaching English, 2(7), 129-144.

Bajrami, L. (2015). Different Approaches for Learner Autonomy in Higher Education. In B. Xhaferri, M. Waldispuhl, B. Eriksson-Hotz, \& G. Xhaferri (eds.), Promoting Learner Autonomy in Higher Education, p.147-156. Tetovo: South East European University.

Balçıkanlı, C. (2010). Learner autonomy in language learning: Student teachers' beliefs. Australian Journal of Teacher Education, 35(1), 90-103.

Bodenhausen, G. V., \& Hugenberg, K. (2009). Attention, perception, and social cognition. In F. Strack, \& J. Förster (Eds.), Social Cognition: The Basis of Human Interaction (pp. 1-22). New York: Psychology Press.

Borg, S. \& Al-Busaidi, S. (2012). Teachers' beliefs and practices regarding learner autonomy. ELT Journal, 66(3), 283-292. doi:10.1093/elt/ccr065

Chan, V., M. Spratt \& G. Humphreys (2002). Autonomous language learning: Hong Kong tertiary students' attitudes and behaviors. Evaluation and Research in Education, 16(1), p.1-18.

Creswell, J. W. (2012). Educational Research: Planning, Conducting and Evaluating Quantitative and Qualitative Research (4 $4^{\text {th }}$ Edition). Boston: Pearson.

Dafei, D. (2007). An exploration of the relationship between learner autonomy and English proficiency. Asian EFL Journal, 24,6-8.

Dang, T. T. (2012). Learner Autonomy Perception and Performance: A study on Vietnamese students in online and offline learning environments. Ph.D. thesis, La Trobe University.

Duong, M. T., \& Seepho, S. (2014). Promoting learner autonomy: A qualitative study on EFL teachers' perceptions and their teaching practices. Proceedings of the International Conference: DRAL 2 /ILA 2014. Available through $<$ http://www.sola. kmutt.ac.th/.../129-137\%20ILA\%20Tham\%20M. pdf $>$, Accessed 05/01/2015 09:32.

Hoang, N. T. T. (2017). What do learners of technology say about self-directed English learning with technology? VNU Journal of Foreign Studies, 33(1), 118-132. 
Holec, H. (1981). Autonomy and foreign language learning. Oxford: Pergamon Press.

Holliday, A. (2003). Social autonomy: Addressing the dangers of culturalism in TESOL. In D. Palfreyman \& R. C. Smith (Eds.), Learner autonomy across Cultures: Language education perspectives (pp. 110-126). New York: Palgrave Macmillan.

Jacobs, G. M., \& Farrell, T. S. (2001). Paradigm Shift: Understanding and Implementing Change in Second Language Education. Available through $<\underline{\text { http://www.tesl-ej.org/ej17/a1.html }>, \quad \text { Accessed }}$ 02/07/2016 18:11.

Joshi, K. (2011). Learner perceptions and teacher beliefs about learner autonomy in language learning. Journal of NELTA, 16(12), 13-29.

Le, X. Q. (2013). Fostering Learner Autonomy in Language Learning in Tertiary Education: An intervention study of university students in Hochiminh city, Vietnam. Ph.D. thesis, Nottingham University.

Little, D. (1999). Learner autonomy is more than a Western cultural construct. In S. Cotterall \& D. Crabbe (Eds.), Learner autonomy in language learning: Defining the field and effecting change (pp. 11-18). Frankfurt am Main: Peter Lang.

Little, D. (2000). Learner autonomy and human interdependence: Some theoretical and practical consequences of a social-interactive view of cognition, learning and language. In B. Sinclair, I. McGrath \& T. Lamb (Eds.), Learner autonomy, teacher autonomy: Future directions, p. 15-23. Essex: Pearson Education Limited.

Littlewood, W. (1999). Defining and developing autonomy in East Asian contexts. Applied Linguistics, 20(1), 71-94.

Muylaert, C. J., Junior., V. S., Gallo, P. R., Neto, M. L. R., Reis, A. O. A. (2014). Narrative interviews: an important source in qualitative research. In Rev Esc Enferm USP, 48(2), 184-189. Available through $<$ http://www.ee.usp.br/reeusp $>$, Accessed $\underline{30 / 07 / 2016}$

National Assembly of Vietnam (2005). Vietnamese Education Law. Law number 38/2005/QH11, 14 June 2005 issued by National Assembly of Vietnam.

Nguyen, T. C. L. (2009). Learner autonomy and EFL learning at the tertiary level in Vietnam. Doctoral Thesis. Victoria University of Wellington. Retrieved from 12 July 2014, http://researcharchive.vuw. ac.nz/handle/10063/1203

Nguyen, T. N. (2014). Learner Autonomy in Language Learning: Teachers'belief. Ph.D. thesis, Queensland University of Technology.

Nunan, D. (1997). Designing and adapting materials to encourage learner autonomy. In P. Benson \& P. Voller (Eds.) Autonomy and Independence in Language Learning (pp. 192-203). London: Longman.
Sinclair, B. (2000). Learner Autonomy and its Development in the Teaching of English to Speakers of Other Language (TESOL). Unpublished $\mathrm{PhD}$ Thesis. University of Nottingham. UK.

Scharle, Á. \& Szabó, A. (2000). Learner Autonomy: A guide to developing learner responsibility. Cambridge: Cambridge University Press.

Sinclair, B. (2000). Learner autonomy: The next phase. In B. Sinclair, I. McGrath, \& T. Lamb (Eds.), Learner autonomy, teacher autonomy: Future directions (pp. 4-14). Essex: Pearson Education Ltd.

Talley, C. P. (2014). Students' Responses to Learner Autonomy in Taiwan: An Investigation into Learners' Beliefs. International Journal of Humanities and Social Science, 4(4), 24-34.

Thomson, C. K. (1996). Self-assessment in self-directed learning: issues of learner diversity. In R. Pemberton, E. S. L. Li, W. W. F. Or, \& H. D. Pierson (Eds.), Taking Control: Autonomy in Language Learning. Hong Kong: Hong Kong University Press.

Trinh, Q. L. (2005). Stimulating Learner Autonomy in English Language Education: A Curriculum Innovation Study in A Vietnamese Context. Ph.D thesis.

Wenden, A. (1991). Learner Strategies for Learner Autonomy. Englewood Cliffs, NJ: Prentice Hall.

Yao, J. \& Li, X. (2017). Are Chinese undergraduates ready for autonomous learning of English listening? - A survey on students' learning situation. The Journal of Language Teaching and Learning, 7(2), 21-35.

Vietnamese Prime Minister (2012). Decision number 711/QD-TTg, 13 June 2012 issued by Prime Minister. 


\title{
QUAN ĐIỂM CỦA SINH VIÊN CHUYÊN NGÀNH TIẾNG ANH VỀ TƯ CHỦ HỌC TẬP TẠI MỘT TRƯờnG ĐẠI HỌC Ở ĐỒNG BẰNG SÔNG CỦU LONG
}

\author{
Lê Thanh Nguyệt Anh \\ Nghiên cưu sinh, Trưòng Đại học Ngoại ngũu, Đại học Huế \\ Khoa Su phạm Ngoại ngũu, Truờng Đại học Đồng Tháp, \\ 783 Phạm Hũu Lầu, Phưòng 6, Tp. Cao Lãnh, Đồng Tháp, Việt Nam
}

Tóm tắt: Nghiên cứu này được thực hiện nhằm khảo sát thực trạng tự học của sinh viên đại học ở Việt Nam. 60 sinh viên chuyên ngành tiếng Anh của một trường đại học vùng sâu ở miền Nam, Việt Nam đã tham gia trả lời cho nghiên cứu này. Phỏng vấn dạng tường thuật đã được sủ dụng để thu thập các dữ liệu cần thiết. Kết quả của nghiên cứu cho thấy hầu hết sinh viên có nhận thức tích cực về tự học và vai trò của tự học ở bậc đại học. Tuy nhiên, sinh viên đạt được những kết quả học tập khác nhau và có những khó khăn trong khi thực hiện tự học. Từ những kết quả này, nghiên cứu chỉ ra rằng vì tự học là một quá trình lâu dài, sinh viên nên tiếp tục kiên nhẫn nỗ lực tự học và nhờ giảng viên hỗ trợ khi cần thiết.

Tù khóa: tự học, tiếng Anh, sinh viên, học tập, thực hành

\section{APPENDIX INTERVIEWING QUESTIONS}

\section{Students' perceptions of definition, role, and demonstration of learner autonomy}

1. How do you understand the term "learner autonomy" in case of EFL students?

2. What do you think about the role of learner autonomy to English majored students at Dong Thap University in the integrated time today and when you are employed to be English teachers or officers in the future?

\section{Students' practices regarding leaner autonomy}

3. Could you share what and how you have learned English autonomously in details? How much time do you spend on learning English every day out of class? How often? Have you set your goals in learning English? How? When? Have you planned your English study? How? When? Can you arrange reasonable time for your English study and your life? How?

How can you search English materials for your study? How do you revise your old English lessons before every test/exam? And when?

4. Which advantages do you meet when learning English autonomously? Give reasons.

5. Which disadvantages do you meet when learning English autonomously? Give reasons.

III. Students' self-assessment of their LA

6. You self-assess your LA in which level: poor, average, good, or excellent. 